\author{
mjr mgr inż. Paweł Lecha) $)^{*}$
}

\author{
a)Akademia Sztuki Wojennej / War Studies University in Warsaw \\ AAutor korespondencyjny / Corresponding author: lech.pawel@yahoo.com
}

\title{
Terroryzm niekonwencjonalny jako potencjalne zagrożenie dla Polski \\ Unconventional Terrorism as a Potential Threat to Poland
}

Технологический терроризм как потенциальная угроза для Польши

\begin{abstract}
ABSTRAKT
Cel: Celem artykułu jest przedstawienie terroryzmu niekonwencjonalnego jako potencjalnego zagrożenia dla Polski. W artykule przeanalizowano możliwości pozyskania broni masowego rażenia oraz przeprowadzenie ataku z jej użyciem na terenie kraju. Analizie poddano również system przeciwdziałania zagrożeniom terrorystycznym w kraju.

Wprowadzenie: Zaangażowanie Polski w walkę z międzynarodowym terroryzmem niesie za sobą zagrożenie związane z przeprowadzeniem odwetowego ataku terrorystycznego. Polska jest adresatem wielu gróźb ze strony terrorystów i wielokrotnie była wymieniona jako miejsce potencjalnego ataku w odwecie za wspieranie interwencji w Iraku i w Afganistanie oraz koalicji walczącej z dżihadystycznym ugrupowaniem - Islamskim Państwem Iraku i Lewantu (ISIS lub ISIL) [6]. Wydarzenia z ostatnich lat udowodniły, że terroryści są nieprzewidywalni, bezwzględni i chcą za wszelką cenę osiągnąć swoje cele. Aby wyrządzić jak największe zniszczenia i wywołać niespotykaną do tej pory panikę i strach, są w stanie użyć każdej dostępnej broni, w tym broni masowego rażenia (BMR). W marcu 2016 roku podczas Szczytu Bezpieczeństwa Nuklearnego w Waszyngtonie eksperci ds. bezpieczeństwa nuklearnego ostrzegali, że każdy kraj jest zagrożony terroryzmem nuklearnym, i że nie ma barier, których terroryści nie są w stanie pokonać, aby zdobyć materiał nuklearny lub radioaktywny. W związku z powyższym warto analizować zagrożenia, jakie mogą być związane z przeprowadzeniem zamachu terrorystycznego z wykorzystaniem BMR, a także jaki jest stan systemu przeciwdziałania terroryzmowi i jego zwalczania w Polsce.

Metodologia: W artykule zastosowano teoretyczne metody badawcze, takie jak analiza i synteza, porównanie, analogia i uogólnienie oraz indukcja i dedukcja. Analizie, porównaniu i dedukcji poddana została literatura polska i międzynarodowa z zakresu terroryzmu, broni masowego rażenia oraz akty normatywne dotyczące przeciwdziałaniu zagrożeniom terrorystycznym w Polsce. Dopełnieniem były synteza, uogólnienie oraz wnioskowanie indukcyjne, które pozwoliło na przedstawienie ogólnych tez oraz szczegółowych twierdzeń omawianych w niniejszym artykule.

Wnioski: W pracy udowodniono, że pomimo istnienia zagrożeń związanych z przeprowadzeniem zamachów terrorystycznych, Polska posiada odpowiednie służby i instytucje do przeciwdziałania temu zjawisku. Wskazane byłoby jednak, aby zadania i kompetencje w tym zakresie zostały określone bardziej precyzyjnie.

Słowa kluczowe: terroryzm niekonwencjonalny, broń masowego rażenia

Typ artykułu: artykuł przeglądowy
\end{abstract}

Przyjęty: 12.07.2016; Zrecenzowany: 23.05.2017; Opublikowany: 30.06.2017;

Proszę cytować: BiTP Vol. 46 Issue 2, 2017, pp. 100-113, doi: 10.12845/bitp.46.2.2017.7;

Artykuł udostępniany na licencji CC BY-NC-SA 4.0 (https://creativecommons.org/licenses/by-nc-sa/4.0/).

\begin{abstract}
Aim: The aim of the article is to present unconventional terrorism as a potential threat to Poland. The article analyses the possibilities of acquiring Weapons of Mass Destruction and conducting an attack in our country. It also analyses the country's terrorism countering system.

Introduction: Poland's involvement in the fight against international terrorism creates a threat of a counter attack by terrorist groups. Poland has received numerous threats of a potential direct attack on its territory by various terrorist groups in retaliation for our involvement in the Iraq and Afghanistan missions, as well as our support for the coalition countering the activities of the Islamic State of Iraq and the Levant (ISIS or ISIL), a jihadist group ${ }^{[6]}$. The incidents that have taken place over the last few years have demonstrated that terrorists are unpredictable and ruthless. Moreover, they will try to reach their goals by any means possible, using any weapon they can get, including Weapons of Mass Destruction. Their aim is to inflict as much damage as they can, and thus induce unprecedented panic and fear. In March, during the 2016 Nuclear Security Summit, experts warned that each country is the potential target of nuclear terrorist attack, and that there are no obstacles terrorists cannot overcome to acquire nuclear weapons or radioactive materials. That is why it is worthwhile analysing all potential threats connected with being attacked with Weapons of Mass Destruction as well as the current state of counter terrorism activity in Poland. Methodology: The article utilises theoretical research methods such as analysis and synthesis, comparison, analogy and generalisation as well as induction and deduction. The analysis, comparison and deduction covered the Polish and foreign literature in the field of terrorism and weapons of mass destruction,
\end{abstract}


and normative acts pertinent to the countering of terrorist threats in Poland. This was supplemented by a synthesis, generalisation and inductive inference, which allowed the presentation of general theses and specific propositions discussed in the article.

Conclusions: It has been proven in the article that despite existing potential risks of terrorist attacks, Poland has all the necessary services and institutions to counteract the phenomenon. However, the need arises to define more precisely counter-terrorism tasks and competences.

Keywords: unconventional terrorism, weapon of mass destruction

Type of article: review article

Received: 12.07.2016; Reviewed: 23.05.2017; Published: 30.06.2017;

Please cite as: BiTP Vol. 46 Issue 2, 2017, pp. 100-113, doi: 10.12845/bitp.46.2.2017.7;

This is an open access article under the CC BY-NC-SA 4.0 license (https://creativecommons.org/licenses/by-nc-sa/4.0/).

\begin{abstract}
АННОТАЦИЯ
Цель: Цель данной статьи - представить технологический терроризм в качестве потенциальной угрозы для Польши. В статье анализируются возможности получения террористами оружия массового поражения и проведение теракта с его использованием на территории Польши. Была проанализирована также система противодействия террористическим угрозам в стране.

Введение: Участие Польши в борьбе с международным терроризмом влечет за собой угрозу связанную с проведением ответного теракта. В адрес Польши поступают многочисленные угрозы со стороны террористов и она неоднократно упоминается ими в качестве потенциального места нападения - реванша за поддержку военной операции в Ираке и Афганистане, а также коалиции, борюшейся с группировкой джихадистов - Исламским государством Ирака и Леванта (ISIS или ISIL) [6]. События последних лет показали, что террористы непредсказуемы, безжалостны и хотят любой ценой достичь своих целей. Для того, чтобы причинить наибольший вред и вызвать беспрецедентную панику и страх, они могут использовать любое имеюшееся оружие, включая оружие массового поражения (ОМП). В марте 2016 года во время Саммита по ядерной безопасности в Вашингтоне эксперты в области ядерной безопасности предупреждали, что каждая страна находится под угрозой ядерного терроризма и нет никаких барьеров, которые террористы не в состоянии преодолеть, чтобы получить ядерный или радиоактивный материал. Поэтому следует проанализировать угрозы, которые могут быть связаны с проведением террористического акта с использованием оружия массового поражения, а также состояние системы предупреждения терроризма и борьбы с ним в Польше.

Методология: В этой статье были использованы теоретические методы исследования, такие как анализ и синтез, сравнение, аналогия и обобшение, а также индукция и дедукция. Анализу, сравнению и дедукции подверглась международная и польская литература в области терроризма, оружия массового поражения, а также нормативные акты по противодействию террористическим угрозам в Польше. Дополнением являлся синтез, обобшение и индуктивные рассуждения, которые позволили также представить обшие и конкретные тезисы и утверждения, указанные в этой статье. Выводы: Исследование показало, что хоть и сушествуют угрозы, связанные с проведением террористических атак, в Польше работают соответствуюшие службы и учреждения для противодействия этому явлению. Однако, следовало бы более точно определить задачи и компетенции в этой области.

Ключевые слова: технологический терроризм, оружие массового поражения

Вид статьи: обзорная статья
\end{abstract}

Принята: 12.07.2016; Рецензирована: 23.05.2017; Опубликована: 30.06.2017;

Просим ссылаться на статью следуюшим образом: BiTP Vol. 46 Issue 2, 2017, pp. 100-113, doi: 10.12845/bitp.46.2.2017.7;

Настояшая статья находится в открытом доступе и распространяется в соответствии с лицензией CC BY-NC-SA 4.0

(https://creativecommons.org/licenses/by-nc-sa/4.0/).

\section{Wprowadzenie}

Termin terroryzm, szczególnie po zamachach z 11 września 2001 roku, wszedł na stałe do codziennego użycia na całym świecie. Mało kto zastanawia się nad jego znaczeniem. Spowodowało to, że właściwie każdy akt przemocy wymierzony w społeczeństwo określany jest tym mianem.

Akty terroru były stosowane od początku historii ludzkości. Już w antycznej Grecji w grze politycznej i wyścigu do władzy posługiwano się skrytobójstwem czy zamachem. W literaturze przedmiotu można odnaleźć, że początki terroryzmu wiążą się z powstaniem w Persji około 1090 roku tajnego zakonu Asasynów [1, s. 32].

\section{Background}

The term 'terrorism', especially following the September $11^{\text {th }}$, 2001 attacks, has been in use throughout the world. However, hardly anyone thinks about its significance. This has led to a situation when almost every act of violence against society is called 'terrorism'.

Acts of terror have happened from the beginning of human history. As early as in ancient Greece, assassinations and attacks were used in political games and in the struggle for power. The literature on the subject shows, however, that the outset of terrorism is associated with the establishing of the secret order of Assassins in Persia around 1090 [1, p. 32]. 
Współcześnie terroryzm nabrał nowego charakteru. Od połowy lat sześćdziesiątych zaczęła wzrastać liczba aktów terrorystycznych popełnianych przez pojedyncze osoby lub grupy (organizacje) oraz rządy (tzw. terroryzm państwowy). Terroryzm stał się ważną metodą walki politycznej wielu ugrupowań próbujących rozwiązywać różne problemy społeczno-polityczne, narodowościowe i religijne. Ataki terrorystyczne mają głównie na celu zastraszenie grupy społecznej, narodowościowej lub religijnej, większej niż ta bezpośrednio poddana atakowi [2, s. 7]. Konieczność dotarcia do opinii publicznej, a nie tylko do bezpośrednich ofiar zamachu, wymaga od terrorystów takiego zaplanowania ataku, by przyciągnąć uwagę telewizji, prasy i radia. Media stają się środkiem przekazu żądań terrorystycznych i prezentacji poglądów głoszonych przez ugrupowania terrorystyczne, a ponadto służą demonstracji (podobnie jak i ataki) siły tych ugrupowań [3, s. 16-18].

Wydarzenia z ostatnich lat udowodniły, że terroryści są nieprzewidywalni, bezwzględni i za wszelką cenę chcą osiągnąć swoje cele. Według danych Europolu tylko w 2015 roku w Europie przeprowadzonych było 211 zamachów terrorystycznych, w których zginęło 151 osób, a rannych zostało 360 [4, s. 14]. Terroryści są w stanie użyć każdej dostępnej broni, w tym BMR, celem wyrządzenia jak największych zniszczeń, a w konsekwencji wywołania niespotykanej do tej pory paniki i strachu. Zastosowanie broni masowego rażenia (BMR) w nowych aktach terroru mogłoby zagrozić bezpieczeństwu zaatakowanego państwa oraz całego regionu.

Od 11 września 2001 roku najbardziej znaną siatką terrorystyczną jest Al-Kaida, międzynarodowa organizacja finansująca i kierująca działalnością islamskich bojowników na całym świecie. Organizacja ta powstała podczas wojny afgańsko-rosyjskiej, a jej rdzeń stanowią weterani wojenni z całego świata islamskiego. Al-Kaidę założył około roku 1988 saudyjski milioner i islamski bojownik Osama bin Laden. Utworzył on w Afganistanie potężną międzynarodową sieć łączącą wszystkich muzułmańskich ekstremistów w różnych krajach. Organizacja posługuje się najnowszymi osiągnięciami techniki, komunikując się również za pomocą portali społecznościowych. Dzięki temu pozostaje w kontakcie z nieznaną liczbą swoich zwolenników we wszystkich krajach arabskich, a także w Europie, Azji i Ameryce [1, s. 4]

Od 2014 roku również bardzo aktywne stało się, wyjątkowo bezwzględne, dżihadystyczne ugrupowanie Islamskie Państwo Iraku i Lewantu (ISIS lub ISIL), które wypowiedziało lojalność Al-Kaidzie i ogłosiło przywrócenie na terytorium Syrii i Iraku kalifatu - ustroju państwowego, który powstał ponad 1,5 tys. lat temu, po śmierci proroka Mahometa. Szacuje się, że ugrupowanie zrzesza ponad 50 tys. bojowników. ISIS prowadzi aktywną kampanię rekrutacyjną wśród zwolenników dżihadu i kalifatu. W związku z tym w szeregach organizacji walczy wielu muzułmanów mieszkających na stałe w krajach Unii Europejskiej. Kolejni ochotnicy, którzy werbowani są na całym świecie, kierują się do Syrii i Iraku, aby wstąpić w szeregi ugrupowania [5]. Należy jednak podkreślić, że najpoważniejszym problemem mogą być osoby, które po odbyciu szkolenia wrócą do Europy i staną się bezpośrednim zagrożeniem dla jej obywateli. Sprzyjać takiemu zjawisku będzie ogromny wzrost masowej nielegalnej migracji. W 2015 roku do krajów Unii Europejskiej przybyło ponad milion uchodźców głównie z Afryki i Bliskiego Wschodu.
Currently, terrorism has gained a new character. Since the mid-1960s, the number of terrorist attacks by individuals, groups or organisations and governments (so-called state terrorism) has increased. Terrorism has become an important tool for numerous groups, in achieving success in the political struggle to remedy perceived socio-political, nationality and religious disparity. Terrorist attacks are mainly aimed at intimidating a specific social, nationality or religious group larger than the directly attacked group [2, p. 7]. The necessity to reach the public, and not only to the victims of an attack, requires the terrorists to plan it in such a way as to attract the attention of television, the press and the radio. The media are becoming the carrier of terrorist demands and of the views professed by terrorist groups, and is also used to demonstrate (similarly to the attacks) the strength of these groups [3, p. 16-18].

The events from the recent years have demonstrated that terrorists are unpredictable, ruthless and willing to achieve their goals at all costs. According to Europol's data, in 2015 alone, in Europe, there were 211 terrorist attacks resulting in 151 fatalities and 360 casualties [4, p. 14]. Terrorists are willing to use any available weapon, including weapons of mass destruction (WMD), in order to generate the highest possible amount of damage, and, as a consequence, to create an unprecedented level of panic and fear. The use of WMD in new acts of terror could threaten the safety of the attacked country and the entire region.

Since 11 September 2001, the best known terrorist organisation is Al-Qaeda, an international organisation funding and managing the world-wide activities of Islamic warriors. The organisation was established during the war between Afghanistan and the Soviet Union, and its core is composed of Islamic war veterans. Al-Qaeda was established around 1988 by Osama bin Laden, a Saudi Arabian millionaire and mujahedeen. He created in Afghanistan a powerful international network joining all pan-national Muslim extremists. The organisation employs the newest technological achievements, and uses up to date social media for communication, among other means. In this way it stays in contact with an unknown number of supporters in all Arabic countries, and also in Europe, Asia and America [1, p. 4].

Since 2014, the Islamic State of Iraq and the Levant (ISIS or ISIL), a particularly ruthless jihadist group has made its presence felt. ISIS has abandoned allegiance to al-Qaeda and announced the restoration of the caliphate in Syria and Iraq i.e. the state governance system created over 1.5 thousand years ago, after the death of prophet Muhammad. It is estimated that the group has enlisted over 50 thousand recruits, and ISIS is leading a world-wide active recruitment campaign among the supporters of jihad and the caliphate. Among these are many Muslims living permanently in EU countries. Volunteers recruited around the world go to Syria and Iraq to join the group [5]. It should, however, be emphasised that the people who return to Europe after training and may become a threat to its citizens are the most important problem. This phenomenon will be facilitated by the tremendous increase in mass illegal migration. In 2015, over a million refugees from Africa and Middle East have fled to European Union countries. 


\section{Terroryzm zagrożeniem dla Polski}

Kiedy po zamachach w Madrycie z 11 marca 2004 roku, śledztwo doprowadziło do Al-Kaidy, było jasne, że groźby kierowane przez Osamę bin Ladena nie są „pustymi słowami”. Okazało się, że zamachy bombowe w Madrycie były odwetem za współpracę Hiszpanii ze Stanami Zjednoczonymi w Afganistanie. W Londynie 7 lipca 2005 r., w tym samym czasie, kiedy w Gleneagles w Szkocji odbywał się szczyt państw G8, doszło do zamachu terrorystycznego, do którego przyznała się nieznana do tej pory organizacja pod nazwą Tajna Grupa Dżihadu Al-Kaidy w Europie. W późniejszych latach miały miejsce kolejne zamachy terrorystyczne, do których przyznała się AlKaida, między innymi atak terrorystyczny w Paryżu przeprowadzony 7 stycznia 2015 roku w siedzibie magazynu satyrycznego „Charlie Hebdo", gdzie zginęło 12 osób. Zamachu dokonali bracia, obywatele francuscy z pochodzenia Algierczycy. Jeden z nich przeszedł kilkumiesięczne szkolenie w obozie Al-Kaidy w Jemenie.

Normalizacja stosunków polsko-izraelskich, poparcie pierwszej wojny w Zatoce Perskiej z 1991 r., udział Polski w koalicji antyterrorystycznej i militarne wsparcie procesu stabilizacji sytuacji w Iraku i w Afganistanie powodują, że nasz kraj jest adresatem wielu gróźb ze strony arabskich terrorystów [6]. Polska wielokrotnie była wymieniona, obok USA, Wielkiej Brytanii, Hiszpanii, Australii, Japonii i Włoch, jako miejsce potencjalnego ataku terrorystów w odwecie za wspieranie interwencji w Iraku i Afganistanie.

Biorąc pod uwagę dynamikę rozwoju fundamentalizmu muzułmańskiego oraz kryzysy migracyjne w Europie, wzrasta prawdopodobieństwo przyjazdu osób związanych z tą ideologią do Polski. Mogą to być osoby, które kończyły polskie wyższe uczelnie oraz posiadają w Polsce krewnych bądź przyjaciół. W tej sytuacji nie można wykluczyć też prób przenikania aktywistów islamskich z organizacji ekstremistycznych do legalnie działających w Polsce związków społeczności arabskiej, jak również wykorzystywania działających w naszym kraju firm prowadzonych przez obywateli państw z regionu Bliskiego Wschodu [6].

Polska nie była dotychczas bezpośrednim celem ataku terrorystycznego, ale nie można wykluczyć, że jest dla organizacji terrorystycznych obiektem zainteresowania do przeprowadzenia zamachu. Aktywnie uczestnicząc w działaniach społeczności międzynarodowej, ukierunkowanych na przeciwdziałanie i zwalczanie terroryzmu, musimy liczyć się z tym, że możemy stać się celem zamachu [7, s. 4].

$\mathrm{Na}$ uwagę zasługuje również zagrożenie terroryzmem związanym z wykorzystaniem BMR. Wprawdzie w Polsce dotychczas nie ujawniono bezpośrednich działań związanych z próbami pozyskiwania na dużą skalę lub użycia czynników chemicznych, biologicznych, radiacyjnych i nuklearnych (CBRN) do działań terrorystycznych, należy jednak zaznaczyć, że organizacje terrorystyczne starają się uzyskać dostęp do substancji i materiałów, które użyte w zamachu zapewniłyby jak największą siłę rażenia i spowodowałyby jak najdotkliwsze straty [7, s. 9].

\section{Terroryzm niekonwencjonalny}

Wszystkie akty terrorystyczne zawierają przemoc lub groźbę jej użycia. W zależności od motywów, celu i sposobu dokonania ataku możemy wyróżnić różne rodzaje terroryzmu. Ze względu na wykorzystane środki walki - przemocy, agresji, ataku i rażenia -

\section{Terrorism as a threat to Poland}

When after the attacks in Madrid of 11 March 2004, the investigation led to Al-Qaeda, it became clear that Osama bin Laden's threats are not just empty words. It turned out that the bomb attacks in Madrid were in revenge for Spain's cooperation with the United States in Afghanistan. On 7 July 2005 in London, at the same time, when in Gleneagles, Scotland, the G8 summit was held, a terrorist attack was launched, for which the previously unknown Secret Organisation of al-Qaeda in Europe claimed responsibility. In the following years further terrorist attacks were carried out by Al-Qaeda, including the Paris attack of 7 January 2015, in the office of the "Charlie Hebdo" satirical magazine, where 12 people died. The attack was launched by brothers of Algerian origin who were French citizens. One of them had undergone a several-month training in Al-Qaeda's camp in Yemen.

The normalisation of relations between Poland and Israel, support for the First Gulf War of 1991, Poland's belonging to the anti-terrorist coalition and our military support for the stabilisation of the situation in Iraq and Afghanistan cause our country to receive many threats from Arab terrorists [6]. Poland has been repeatedly mentioned, next to the USA, the United Kingdom, Spain, Australia, Japan and Italy, as a place of potential terrorist attacks in retaliation for supporting the interventions in Iraq and Afghanistan.

With regard to the dynamic development of Muslim fundamentalism and the migration crises in Europe, the probability that individuals associated with this ideology will come to Poland is growing. These can be people who studied at Polish universities and have relatives or friends in Poland. In such circumstances, it cannot be ruled out that Islamic activists from extremist organisations will try to infiltrate Arabic communities legally operating in Poland, and that the citizens of Middle Eastern countries will try to use companies running business activities in our country [6].

Poland has not been a direct target of terrorist attacks before, but it cannot be ruled out that our country is an object of interest for terrorist organisations. By actively participating in the activities of international communities directed at counteracting and combatting terrorism, we must take into consideration that we may become the target of an attack [7, p. 4].

The threat of terrorism related to the use of WMD also requires attention. Despite the fact that in Poland, no direct attempts have been made to obtain or use chemical, biological, radiological or nuclear agents (CWMD) for acts of terrorism, it should be mentioned that terrorist organisations are trying to gain access to such substances and materials which, if used in an attack, would ensure the greatest striking power and cause vast damage [7, p. 9].

\section{Unconventional terrorism}

All terrorist acts involve violence or threats to use such. Still, depending on the motives, the purpose and the method of an attack, various types of terrorism can be distinguished. Due to the methods used by terrorist groups or individuals, - violence, 
przez ugrupowania terrorystyczne lub pojedynczych terrorystów możemy wyróżnić terroryzm konwencjonalny i niekonwencjonalny. Zatem istotą terroryzmu konwencjonalnego jest wykorzystywanie w celu rażenia różnego rodzaju ładunków wybuchowych, nasobnych, pojazdów i samolotów adaptowanych, środków artyleryjskich, zestawów rakietowych itd. Natomiast w terroryzmie niekonwencjonalnym stosowanymi materiałami destrukcyjnymi są środki promieniotwórcze, chemiczne, biologiczne lub materiały rozczepiane (broń jądrowa).

Terroryzm niekonwencjonalny można podzielić, adekwatnie do broni masowego rażenia, na chemiczny, biologiczny, jądrowy i radiologiczny.

\section{Terroryzm radiologiczny}

Broń radiologiczna to środek walki, w którym czynnikiem rażącym jest rozproszony materiał promieniotwórczy. Może on być uzyskany zarówno z ośrodków realizujących cywilne i wojskowe programy jądrowe, jak i z odpadów promieniotwórczych z reaktorów badawczych bądź środków promieniotwórczych stosowanych w przemyśle lub medycynie [8, s. 8].

Zamach terrorystyczny może zostać przeprowadzony z użyciem radiologicznej brudnej bomby poprzez wykorzystanie np. takich materiałów radiologicznych jak zużyte pręty paliwowe reaktora jądrowego, które przy pomocy ładunku konwencjonalnego zostaną rozproszone w miejscu eksplozji.

\section{Terroryzm jądrowy}

Terroryzm jądrowy polega na wykorzystaniu broni jądrowej, gdzie czynnikami rażenia są: fala uderzeniowa o wielkiej sile burzącej, promieniowanie cieplne wzniecające pożary, promieniowanie jonizujące i promieniotwórcze skażenie terenu oraz impuls elektromagnetyczny. Skutki takiego wybuchu jądrowego są dużo większe od skutków działania broni konwencjonalnej. Bomba jądrowa określona jako 1-kilotonowa wyzwala taką samą ilość energii co wybuch 1000 ton TNT. W związku z powyższym niewątpliwie atak z użyciem broni jądrowej byłby najbardziej spektakularnym zamachem terrorystycznym, a co za tym idzie pożądanym przez zamachowców.

Broń jądrowa budowana na potrzeby terrorystów charakteryzowałaby się innymi cechami niż typowe konstrukcje. Przede wszystkim można byłoby ją łatwo zbudować, wykorzystując bardziej dostępne materiały. Powinna mieć możliwie jak najmniejsze rozmiary np. takie, aby można było transportować ją samochodem. Teoretycznie zbudowanie takiej bomby jest możliwe. W Stanach Zjednoczonych już ponad pół wieku temu w ramach projektu Special Atomic Demolition Munition (SADM) zbudowano niewielką głowicę W-54, którą z powodzeniem przetestowano w 1962 roku. Jej masa wynosiła około $30 \mathrm{~kg}$, siła wybuchu odpowiadała $1 \mathrm{kt}$, natomiast wielkość była na tyle mała, aby mogła być użyta $w$ roli „bomby walizkowej”. Jednak głowica W-54 została zaprojektowana do pocisków Davy Crockett, które mogły być wystrzelone z wyrzutni o kalibrze 155 mm M29. Cały zestaw, głowica wraz z wyrzutnią była obsługiwana przez trzyosobową drużynę [9].

„Bomba walizkowa" wymaga przede wszystkim wysokiej jakości materiału rozszczepialnego np. silnie wzbogaconego aggression, attack and destruction - a division can be made into conventional and unconventional terrorism. Therefore, the essence of conventional terrorism is the use, for destructive purposes, of various types of explosives, suicide vests, adapted vehicles and airplanes, artillery weapons, missile sets, etc. However, in unconventional terrorism, the destructive materials include radiological, chemical, biological or fissile materials (nuclear weapons).

Unconventional terrorism can be divided, in parallel to weapons of mass destruction, into chemical, biological, nuclear and radiological.

\section{Radiological terrorism}

Radiological weapons are weapons in which dispersed radioactive material is the destructive agent. These can be obtained both from centres implementing civil and military nuclear programmes and from radioactive waste or agents used in industry or medicine [8 p. 8].

A terrorist attack can be carried out with the use of a crude nuclear explosive device built with such radiological materials as used fuel rods from a nuclear reactor, dispersed at the place of the explosion with a conventional explosive.

\section{Nuclear terrorism}

Nuclear terrorism consists of using nuclear weapons. These have the following destructive agents: a shockwave with a massive destruction force, heat radiation causing fires, ionising radiation and radioactive terrain contamination, as well as electromagnetic impulse disruption of electronics. The effects of such a nuclear explosion are much more severe than in the case of conventional weapons. A 1-kilotonne nuclear bomb releases the same amount of energy as the explosion of 1000 tonnes of TNT. Due to the above, undoubtedly an attack involving nuclear weapons would be a most spectacular act of terrorism - one most desirable from the attackers' perspective.

Nuclear weapons built for terrorist purposes would differ from the typical bombs of such type. First of all, it must be possible to build it using the most easily available materials. It should also be relatively small, i.e. it must be transportable by a car or light van. Theoretically, it is possible to build such a bomb. In the United States, over 50 years ago, under the Special Atomic Demolition Munition (SADM) project, a small W- 54 warhead was constructed, and successfully tested in 1962. Its weight was around $30 \mathrm{~kg}$, and the explosion force corresponded to 1 kilotonne, while its size was small enough for it to be deemed a "suitcase bomb". Moreover, the W-54 warhead was designed for fitting to the Davy Crockett rocket (M29 launcher) system missiles, which could be launched from the $155 \mathrm{~mm}$ M29 launcher. The entire set of warhead with the launcher was operated by three people [9].

The suitcase bomb requires a high-quality fissile material, e.g. strongly reinforced uranium and high-class specialists to build the bomb. Designing a nuclear weapon is complicated 
uranu oraz wysokiej klasy specjalistów do jej budowy. Zaprojektowanie broni jądrowej jest na tyle skomplikowane, że ataki z jej użyciem są mało prawdopodobne, ale jednak możliwe. Aby pozyskać broń jądrową, terroryści próbują różnych sposobów np. zakupu z nielegalnego źródła lub kradzieży.

\section{Terroryzm chemiczny}

Terroryzm chemiczny zakłada wykorzystanie bojowych środków trujących (BŚT) lub innych wysokotoksycznych związków chemicznych.

Bardzo duży wpływ na zachowanie się bojowych środków trujących w momencie jej użycia mają ich właściwości fizyczne i chemiczne. Środki trujące są stosowane w postaci par, aerozoli lub kropel. Skażenie powietrza lub powietrza i terenu wraz z obiektami, które się na nim znajdują, następuje w zależności od rodzaju i ilości środka trującego. Przygotowanie środka trującego do użycia w zamachu jest związane przede wszystkim z procesami dyspersji i parowania. Procesy te zależą od właściwości fizykochemicznych środka oraz od warunków atmosferycznych, ukształtowania terenu, rodzaju powierzchni itp. Zasadniczy wpływ na zachowanie się środków trujących mają: prężność pary nasyconej i lotność środka trującego, temperatura parowania, współczynnik dyfuzji, lepkość, napięcie powierzchniowe, ciężaru gazu względem powietrza i temperatura krzepnięcia [10, s. 63-64].

Związki chemiczne tzw. podwójnego przeznaczenia to różnego rodzaju toksyczne substancje chemiczne wykorzystywane we współczesnym przemyśle, produkowane lub używane w procesach technologicznych w prawie każdym dużym zakładzie przemysłowym.

Jednym z możliwych sposobów skażenia przy użyciu tej broni jest rozpylenie środka chemicznego w postaci aerozolu w miejscach publicznych, przede wszystkim w obiektach zamkniętych. Równie prawdopodobne jest rozprzestrzenienie środków chemicznych poprzez system zaopatrzenia w wodę do picia. Zamachowcy mogą wykorzystać także konwencjonalny ładunek wybuchowy i obłożyć go pojemnikami zawierającymi środki chemiczne. Skutki takiego ataku są trudne do przewidzenia ze względu na zmienność warunków meteorologicznych. Będą zależały od rodzaju użytego środka, warunków pogodowych i sposobu dyspersji.

\section{Terroryzm biologiczny}

Bioterroryzm jest to nielegalne i bezprawne "użycie czynników biologicznych w celu wywołania strat w ludziach lub zwierzętach bądź spowodowania uszkodzeń roślin" [11, s. 61]. Słownik terminów i definicji NATO określa broń biologiczną jako "środki materiałowo-techniczne, które przenoszą, rozprzestrzeniają lub rozsiewają środki biologiczne, w tym również stawonogi" [12, s. 24].

Broń biologiczna jest rodzajem broni masowego rażenia, w której ładunkiem bojowym są różnego rodzaju drobnoustroje chorobotwórcze. Z uwagi na wykorzystane czynniki chorobotwórcze można podzielić je na trzy grupy: bakterie, wirusy oraz toksyny. Zatem broń biologiczna to środek masowego zakażenia ludzi, zwierząt i pożywienia drobnoustrojami chorobotwórczymi oraz toksynami, które wytwarzane są przez bakterie i wirusy [13, s. 19].

Zastosowanie broni biologicznej w ataku terrorystycznym może nastąpić zarówno przez skażenie powietrza, wody lub gle- enough to make it rather unlikely, but possible, for such attacks to occur. In order to obtain nuclear weapons, terrorists are trying various methods, e.g. purchasing from illegal sources or stealing.

\section{Chemical terrorism}

Chemical terrorism involves the use of chemical weapon agents (CWA) or other highly toxic chemical compounds.

The physical and chemical properties of chemical weapon agents have a very high impact on their effects. Chemical agents take the form of vapours, aerosols or drops. The contamination of air or air and terrain with objects located on them depends on the type and amount of the chemical agent. The preparation of a chemical agent to be used in an attack is mainly associated with the dispersion and evaporation processes. These processes depend on the physical and chemical properties of the agent and from atmospheric conditions, the lay of the land, the type of the area, etc. The impact on the behaviour of chemical agents depends mainly on: the saturated vapour pressure and the volatility of the chemical agent, temperature of evaporation, the diffusion coefficient, viscosity, surface tension, the weight of gas in relation to air and the coagulation temperature [10, p. 63-64].

The so-called dual-use chemical compounds are various types of toxic chemicals used in contemporary industry produced or used in technological processes in almost every large industrial plant.

One of the possible ways of causing contamination with this weapon is spraying a chemical agent in the form of aerosol in a public place, especially in a closed space. It is equally possible to spread chemicals through the drinking water supply system. Attackers may also use conventional explosives and surround them with containers with chemical agents. The effects of such an attack are difficult to predict due to the changeability of meteorological conditions. The damage depends on the type of agent used, weather conditions and dispersion methods.

\section{Biological terrorism}

Bioterrorism is the illegal and unlawful use of biological agents so as to cause the death of people or animals or to destroy plants" [11, p. 61]. The NATO glossary of terms and definitions defines a biological weapon as "an item of material which projects, disperses, or disseminates a biological agent, including arthropod vectors" [12 p. 24].

Biological weapons are a type of weapon of mass destruction involving the dispersion of various types of pathogenic microorganisms. Due to their application, pathogenic factors can be divided into three groups: bacteria, viruses and toxins. Therefore, biological weapons are agents of mass contamination consisting of pathogenic microorganisms and toxins produced by bacteria and viruses, which can be used on people, animals and food items [13, p. 19].

The employment of biological weapons in a terrorist attack can take the form of direct contamination via air, water or 
by, jak i przez nosicieli choroby: zakażone insekty, gryzonie lub ludzie. Jednym z realnych sposobów ataku przez bioterrorystów jest skażenie powietrza przez rozpylenie np. aerozolu biologicznego. Wynika to z faktu, że urządzenia do wytwarzania aerozoli są łatwo dostępne oraz większość czynników biologicznych może być łatwo przenoszona drogą powietrzną. Obiektami takiego ataku będą przede wszystkim miejsca posiadające wydajne systemy klimatyzacyjne, budynki użytku publicznego i stacje metra, a także wszystkie miejsca, w których gromadzą się ludzie: dworce kolejowe, porty lotnicze, centra handlowe, obiekty sportowe i kulturalne, budynki rządowe i publiczne, miejsca koncentracji wojsk, miejsca publicznych imprez masowych.

Innym sposobem ataku może być skażenie żywności, wody lub gleby, gdzie bioterroryści mogą wykorzystać drobnoustroje. Najbardziej narażone na taki atak mogą być punkty zbiorowego żywienia lub ujęcia wody pitnej.

Przeprowadzono wiele symulacji skutków zastosowania broni biologicznej. Miedzy innymi eksperci ze Światowej Organizacji Zdrowia WHO oszacowali, że gdyby rozpylić z samolotu, z wysokości ok. $2 \mathrm{~km}$ i zgodnie z kierunkiem wiatru, $50 \mathrm{~kg}$ drobnoustrojów chorobotwórczych nad obszarem zamieszkałym przez 500 tysięcy ludzi, to można spodziewać się następujących strat przy użyciu zarodników wąglika: 95 tys. zgonów, 125 tys. zachorowań z możliwością przeżycia [13, s. 21].

Przy zastosowaniu broni biologicznej oprócz wysokich strat w ludziach trzeba spodziewać się również znacznych strat ekonomicznych. Symulacje przeprowadzone w Stanach Zjednoczonych dowodzą, że gdy zachoruje 100 tys. ludzi, to koszty postępowania (diagnostyka, leczenie, rehabilitacja itd.) wyniosą:

- przy wągliku: 26,3 mld USD,

- przy tularemii: 5,5 mld USD [14].

\section{Możliwe sposoby pozyskania przez terrorystów broni masowego rażenia}

Rozważając możliwości pozyskania przez terrorystów broni masowego rażenia, wskazane jest uwydatnić, że oprócz posiadania środka bojowego konieczne jest dysponowanie odpowiednim środkiem przenoszenia.

Terroryści mogą pozyskać broń masowego rażenia z zasobów państwowych bądź wyprodukować ją samodzielnie. Niestabilności poszczególnych regionów świata (zwłaszcza na Bliskim Wschodzie) towarzyszy niebezpieczne zjawisko proliferacji broni masowego rażenia i środków jej przenoszenia. Pozyskanie BMR przez organizacje terrorystyczne jest uzależnione od możliwości dostępu do tego rodzaju broni i stosowanych systemów ochrony w danym kraju. Według Departamentu Obrony USA bronią jądrową i jej komponentami dysponuje 12 państw, bronią biologiczną 13, a chemiczną 19 państw na świecie [15, s. 65]. Według tych danych bakteriami wąglika dysponuje obecnie na całym świecie kilkaset ośrodków. W ich posiadaniu, oprócz USA i Rosji, są także Chiny, Indie, Iran, Izrael, Korea Północna, Kuba i Pakistan. Technologie produkcji i przenoszenia broni biologicznej posiada ponad 20 innych krajów, które dysponują ok. 40 rodzajami śmiercionośnych drobnoustrojów. Inaczej jest zabezpieczona BMR w krajach ustabilizowanych politycznie i ekonomicznie np. w USA, a inaczej soil, or of indirect contamination through vectors or carriers: infected insects, rodents or people. One of the realistic methods of bioterrorist attack is air contamination by spraying, e.g. biological aerosols. This is due to the fact that aerosol producing equipment is easily available and most biological agents can be easily transferred through air. Such an attack can focus on places with efficient air-conditioning systems, as in public utility buildings and underground stations, and in all places where large numbers of people gather: railway stations, airports, shopping malls, sports and cultural facilities, government and public buildings, army stationing locations and mass event venues.

Another method of attack is food, water or soil contamination, for which bioterrorists can use microorganisms. Collective catering establishments or drinking water intakes are the most prone to such attacks.

Numerous simulations of the effects of using biological weapons have been performed. For instance, experts from the World Health Organisation estimated that if $50 \mathrm{~kg}$ of pathogenic microorganisms (Bacillus anthracis) were sprayed from a plane at a height of approx. $2 \mathrm{~km}$ in line with the wind direction over an area inhabited by 500 thousand people, the following losses could be expected: 95 thousand deaths, 125 thousand infections with some possibility of survival [13, p. 21].

Though bioterrorism, apart from human losses, considerable financial losses can also be expected. Simulations carried out in the United States show that with 100 thousand infected people, the costs of medical procedures (diagnostics, treatment, rehabilitation, etc.) are as follows:

- for Bacillus anthracis: USD 26.3 billion,

- for Francisella tularensis: USD 5.5 billion [14].

\section{Possible ways of obtaining weapons of mass destruction by terrorists}

Considering the possibilities of obtaining weapons of mass destruction by terrorists, it is necessary to emphasise that apart from having the weapon agent, a suitable delivery vehicle is required.

Terrorists can obtain weapons of mass destruction from national resources or produce them themselves. The instability of specific regions of the world (especially the Middle East) is accompanied by the dangerous phenomenon of the proliferation of weapons of mass destruction and their delivery vehicles. Obtaining WMDs by terrorist organisation depends on access to such weapons and the protection systems applied by a given country. According to the US Department of Defense, nuclear weapons and their components are held by 12 countries, biological weapons - by 13 countries, and chemical weapons - by 19 countries in the world [15, p. 65]. According to the above data, currently, Bacillus anthracis can be found in several hundred centres throughout the world. In addition to the USA and Russia, it is held by China, India, Iran, Israel, North Korea, Cuba and Pakistan. The technologies of producing and delivering biological weapons are available to over 20 other countries, who have approx. 40 types of lethal microorganisms at hand. WMDs are secured to a varying degree in politically and economically stable countries such as 
w byłych republikach radzieckich. Łatwiejszy dostęp do broni jądrowej lub radiologicznej terroryści mogą mieć w Pakistanie niż np. w Wielkiej Brytanii. Ten rodzaj broni w Pakistanie jest dostępny, a wielu funkcjonariuszy służb specjalnych tego kraju popiera islamskie organizacje terrorystyczne zaangażowane w walce w Afganistanie czy Kaszmirze [16, s. 37].

\section{Pozyskanie BMR z zasobów państwowych}

Szczególne zagrożenie stanowi możliwość pozyskania broni masowego rażenia z zasobów państwowych w państwach skonfliktowanych wewnętrznie o słabej strukturze bezpieczeństwa. Takie możliwości posiadają zwłaszcza organizacje terrorystyczne wspierane w przeszłości przez państwa, które z czasem utraciły nad nimi kontrolę np. palestyński Hamas czy też organizacje powołane przez Pakistan do działań w Kaszmirze. Terroryści mogą wejść $w$ posiadanie broni biologicznej oraz chemicznej z zasobów państwa od fanatyków religijnych zatrudnionych w laboratoriach oraz dzięki pomocy niektórych funkcjonariuszy państwowych lub też mogą ją ukraść.

Eksperci WHO nie wykluczają, że przedstawiciele organizacji terrorystycznej Al-Kaida dysponują zarodnikami laseczki wąglika. Wyprodukowane przez naukowców byłego Związku Radzieckiego laseczki wąglika zostały przetransportowane do Czeczenii oraz Korei Północnej, a byli agenci KGB sprzedali próbki laseczek Irakowi, skąd wirus trafił do organizacji terrorystycznej Al-Kaida [17, s.188-189].

Kradzież jest mniej prawdopodobnym sposobem pozyskania BMR przez organizacje terrorystyczne. Jednakże niebezpieczeństwo stanowią niektóre składnice, w których od zakończenia II wojny światowej przechowywana jest różnego rodzaju broń chemiczna. W około 400 miejscowościach na terenie Rosji magazynowana jest broń chemiczna pochodząca jeszcze z czasów drugiej wojny światowej. Pomimo zachowania odpowiednich środków ochrony, znane są przypadki kradzieży groźnych substancji. Kradzież substancji promieniotwórczej miała miejsce m.in. w styczniu 2002 roku w zakładach chemicznych w Orłowce w Kirgizji, gdzie niezidentyfikowani sprawcy wywieźli z fabryki około 460 kg tlenku europu przechowywanego w kontenerach [18, s. 33].

\section{Wyprodukowanie BMR}

Organizacje terrorystyczne mogą wyprodukować we własnym zakresie tylko proste odmiany trucizn chemicznych i patogenów biologicznych, ponieważ poziom technologiczny wymagany do produkcji środków chemicznych i biologicznych jest bardzo wysoki. W tym celu mogą zostać wykorzystane bazy przemysłu farmaceutycznego i małych laboratoriów. Wyprodukowanie BMR we własnym zakresie gwarantuje terrorystom nie tylko pełne zaskoczenie jej użycia, ale też w istotny sposób zabezpiecza terrorystów przed infiltracją ze strony służb wywiadowczych lub kontrwywiadowczych, jak może mieć to miejsce w przypadku prób pozyskania jej z zasobów państwowych.

Pomimo dużego postępu technicznego i dostępu do nowych technologii wyprodukowanie np. sarinu wymaga wysokiego poziomu wiedzy teoretycznej $w$ dziedzinie chemii organicznej i doświadczenia technologicznego $w$ tym zakresie. W laboratoriach mogą być produkowane chemiczne bojowe środki trujące star- the USA and in the former Soviet republics. However, terrorists can have easier access to nuclear or radiological weapons in Pakistan than, for instance, in the United Kingdom. These weapons are available in Pakistan, and many special forces officers in this country support Islamic terrorist organisations involved in Afghanistan or Kashmir [16, p. 37].

\section{Obtaining WMDs from state resources}

A particularly serious threat is posed by the possibility of obtaining weapons of mass destruction from state resources in countries affected by internal conflicts with a weak security structure. This is possible especially for a terrorist organisation which was once supported by a state which then eventually lost its control over them. e.g. the Palestinian Hamas or organisations established by Pakistan for operations in Kashmir. Terrorists may acquire biological or chemical weapons from state resources from religious fanatics employed in laboratories and with the help of some state officers, or steal them.

WHO experts do not rule out the possibility that Al-Qaeda members have access to Bacillus anthracis. Produced by the scientists of the former Soviet Union, Bacillus anthracis was transported to Chechnya and North Korea, and former KGB agents are known to have sold samples to Iraq, from where the virus reached Al-Qaeda [17, p. 188-189].

Theft is a less probable method of obtaining WMDs by terrorist organisations. However, there are some depots where, since the end of World War II, various types of chemical weapons have been stored. In approx. 400 localities in Russia alone, chemical weapons from the times of World War II are still in storage. Despite applying suitable protection measures, there are cases of hazardous substances having been stolen. In January 2002, for example, radioactive substances were stolen from the chemical plant in Orlovka, Kyrgyzstan, where unidentified perpetrators took from the plant approximately $460 \mathrm{~kg}$ of europium oxide stored in containers [18, p. 33].

\section{Producing WMDs}

Currently, terrorist organisations can produce only simple varieties of chemical poisons and biological pathogens, as the technological level required to produce chemical and biological agents is very high. The pharmaceutical industry and small laboratories can be used as a basis for such production. Manufacturing WMDs independently guarantees terrorists not only the possibility of a completely unexpected use, but also secures them from infiltration by intelligence and counterintelligence services, which may be the case when attempts are made to obtain such from state resources.

Despite the considerable technological progress and ease of access to new technologies, producing, e.g., sarin requires advanced theoretical knowledge in the field of organic chemistry and technological experience in this area. Laboratories may produce chemical weapon agents of older generations, 
szej generacji pod warunkiem uzyskania dostępu do składników wyjściowych objętych kontrolą i monitoringiem międzynarodowym. Po zamachu w 1995 roku w Japonii z użyciem trującego gazu - sarinu, okazało się, że użycie przez terrorystów bojowych środków trujących jest możliwe. Japońska sekta Aum Shinrikyo podjęła próby produkcji wysokiej jakości chemicznych środków trujących i efektywnych urządzeń do ich rozpylania. Jednakże pomimo doskonale wyposażonego zaplecza laboratoryjnego, wykształconego personelu naukowo-technicznego zatrudnionego w laboratorium oraz zaangażowania poważnych środków finansowych, sekta nie uzyskała zdolności umożliwiających zastosowanie sarinu na skalę masową. W zamachu przeprowadzonym w 1995 roku zginęło 12 osób [19].

Wysoka dynamika postępu technicznego może sprzyjać próbie podjęcia przez terrorystów produkcji broni biologicznej i chemicznej. Stały postęp w dziedzinie biotechnologii i inżynierii genetycznej wpływa na uproszczenie procesu pozyskiwania oraz obniżenie kosztów produkcji niektórych niebezpiecznych wirusów, bakterii i toksyn. W rezultacie w perspektywie dziesięciolecia może dojść do opanowania produkcji prostych form broni biologicznej przez niektóre organizacje terrorystyczne.

Dotychczas poza zasięgiem organizacji terrorystycznych była broń jądrowa i komponenty do broni radiologicznej. Ten rodzaj broni może znaleźć się w posiadaniu organizacji terrorystycznych jedynie w wyjątkowej sytuacji politycznej oraz militarnej na świecie np. w przypadku utraty przez państwo posiadające broń jądrową kontroli nad własnym arsenałem i nagłego załamania się struktur władzy państwowej. Wykorzystanie przez terrorystów broni jądrowej nie jest wprawdzie wykluczone, ale bardzo mało prawdopodobne. provided that components subject to international control and monitoring are obtained. Following the attack of 1995, in Japan, - involving sarin it turned out that the use of chemical weapon agents by terrorists is possible. The Japanese Aum Shinrikyo cult made attempt to produce high-quality chemical weapon agents and effective delivery vehicles. However, despite the excellently equipped laboratories, highly educated scientific and technological personnel and substantial funds, the cult could not release sarin on a mass scale. The attack of 1995 led to the death of 12 people [19].

The high rate of technological progress can facilitate terrorists' attempts to produce biological and chemical weapons. Steady progress in the field of biotechnology and genetic engineering simplifies the process of obtaining some dangerous viruses, bacteria and toxins and lowers the costs of producing them. As a result, in ten years' time some terrorist organisations may be able to produce simple forms of biological weapons.

So far nuclear weapons and radiological weapon components have been out of the reach of terrorist organisations. These type of weapons can be acquired by terrorist organisations only in a unique political or military situations, i.e. when a country in possession of nuclear weapons loses control over its arsenal or when the state's power structure collapses suddenly. The use of nuclear weapons by terrorists cannot be ruled out but it is highly improbable.

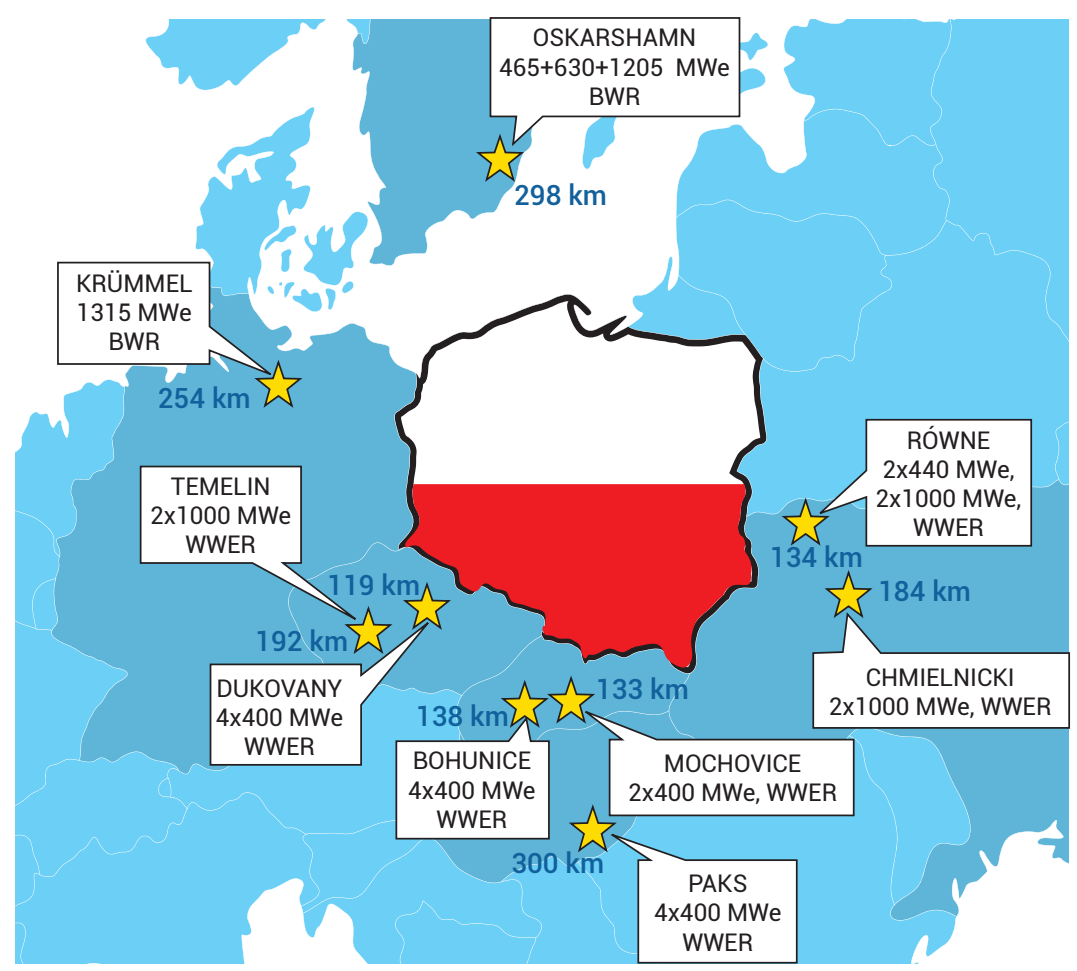

Rycina 1. Elektrownie jądrowe zlokalizowane w odległości do 310 km od granic Polski

Figure 1. Nuclear power plants within $310 \mathrm{~km}$ from Polish borders

Źródło: Opracowanie własne na podstawie Krajowego Planu Zarządzania Kryzysowego 2012.

Source: Own elaboration based on the National Crisis Management Plan, 2012. 


\section{Uwolnienie niebezpiecznych substancji o właściwościach BMR}

W wyniku działalności terrorystycznej istnieje również możliwość uwolnienia niebezpiecznych substancji, które są surowcami w procesach produkcyjnych, półproduktach, gotowych wyrobach oraz odpadach. Ze względu na swoje właściwości fizyczno-chemiczne oraz biologiczne stwarzają one zagrożenie dla ludzi i środowiska równoznaczne z użyciem BMR. Jednocześnie ze względu na swoją powszechność występowania, łatwość dostępu i różnorodność tego typu działania mogą być w dowolnym czasie obiektem lub celem działalności terrorystycznej.

Szczególnymi źródłami tego typu zagrożeń mogą być obiekty energetyki jądrowej, przemysłu chemicznego oraz środki transportu substancji niebezpiecznych.

W Polsce nie posiadamy obiektów energetyki jądrowej, jednak jesteśmy także narażeni na skutki potencjalnych katastrof radiacyjnych. Wynika to z tego, że otaczają nas państwa dysponujące elektrowniami jądrowymi.

Do lokalnych źródeł zagrożenia radiacyjnego w naszym kraju zalicza się Ośrodek Badań Jądrowych (reaktory badawcze) i Zakład Unieszkodliwiania Odpadów Promieniotwórczych (ZUOP) w Świerku, Krajowe Składowisko Odpadów Promieniotwórczych (KSOP) w Różanie oraz zakłady przemysłowe używające źródła promieniowania jonizującego. Zgodnie z krajowym planem postępowania $z$ odpadami promieniotwórczymi i wypalonym paliwem jądrowym, który został przyjęty uchwałą nr 195 Rady Ministrów z dnia 16 października 2015 roku, planowane jest ostateczne zamknięcie KSOP w Różanie i budowa nowego składowiska powierzchniowego odpadów promieniotwórczych (NSPOP), składowiska głębokiego odpadów promieniotwórczych (SGOP), w tym realizacja programu Polskiego Podziemnego Laboratorium Badawczego (PURL).

\section{Releasing hazardous substances with WMD properties}

Terrorist activities can also result in releasing hazardous substances used as materials in production processes, as well as the semi-finished items and ready products and waste. Due to their physical, chemical and biological properties, they are equally hazardous for people and the environment as WMDs. However, due to the popularity, ease of access and diversity of operations, such items can be the object or target of terrorist activities.

Nuclear power and chemical industry facilities and means of transportation of hazardous substances are particularly dangerous sources of such threats.

In Poland, we have no nuclear power facilities, but we are subject to the effects of potential radiation catastrophes. This stems from the fact that we are surrounded by countries with nuclear power plants.

The local sources of radiation threats in our country include the Nuclear Research Centre (research reactors) and the Radioactive Waste Management Plant (ZUOP) in Świerk, the National Radioactive Waste Repository (KSOP) in Różan and industrial plants using ionising radiation sources. According to the National Plan of Radioactive Waste and Spent Nuclear Fuel Management adopted by way of Resolution of the Council of Ministers No. 195 of 16 October 2015, it is planned to definitely close KSOP in Różan and to create the New Surface Radioactive Waste Repository (NSPOP) and the Deep Radioactive Waste Repository (SGOP), including the implementation of the Polish Underground Research Laboratory (PURL) programme.

Tabela 2. Planowane zużycie paliwa jądrowego wykorzystywanego w reaktorze badawczym MARIA Table 2. Planned consumption of nuclear fuel used in the MARIA research reactor

\begin{tabular}{ccc}
\hline Lata / Years & Zużycie 20 zestawów/rok / 20 sets/year & Zużycie 25 zestawów/rok /25 sets/year \\
\hline do $2040 \mathrm{r}$ / / up to 2040 & 540 zestawów / sets $-191 \mathrm{~m}^{3}$ & 675 zestawów / sets $-238 \mathrm{~m}^{3}$ \\
\hline do $2050 \mathrm{r}$ / / up to 2050 & 740 zestawów / sets $-261 \mathrm{~m}^{3}$ & 925 zestawów /sets $-327 \mathrm{~m}^{3}$ \\
\hline
\end{tabular}

Źródło: Krajowy plan postępowania z odpadami promieniotwórczymi i wypalonym paliwem jądrowym.

Source: The National Plan of Radioactive Waste and Spent Nuclear Fuel Management.

Ponadto toksyczne środki przemysłowe są używane w produkcji, magazynowane oraz transportowane przez ponad 500 zakładów przemysłowych znajdujących się na terytorium kraju [20, s. 189]. Mogą one stać się potencjalnym celem ataku terrorystycznego.

\section{Zapobieganie zagrożeniom terrorystycznym}

Terroryzm jest zjawiskiem globalnym, dlatego też stanowi poważne wyzwanie dla organizacji i instytucji państwowych oraz międzynarodowych. Kluczową kwestią w zapobieganiu terroryzmowi jest rozpoznanie i monitorowanie jednostek oraz grup, które mogą dokonać ataku terrorystycznego. Krajowe i międzynarodowe organy odpowiedzialne za analizę i wymianę informacji o zagrożeniach
Furthermore, there are over 500 industrial plants in the country using, storing and transporting the toxic industrial agents [20, p. 189] which may become a potential target of terrorist attack.

\section{Preventing terrorist threats}

Terrorism is a global phenomenon, which is why it constitutes a serious threat for national and international organisations and institutions. The key issue in preventing terrorism is to recognise and monitor units and groups which may carry out a terrorist attack. National and international bodies responsible for the analysis and exchange of information on terrorist 
terrorystycznych ewoluują zarówno w zakresie sposobów działania, jak i kompetencji [21, s. 64]. Zgodnie z przyjętą przez Prezydenta RP w dniu 13 listopada 2007 r. Strategią Bezpieczeństwa Narodowego RP Polska popiera rozwój prawa międzynarodowego i zapewnienie jego powszechnego poszanowania oraz będzie zabiegać o rozwój norm prawnych, które będą skutecznymi narzędziami w zwalczaniu zagrożeń związanych z proliferacją broni masowego rażenia oraz terroryzmem [22, s. 14].

Istotą przeciwdziałania terroryzmowi jest wdrażanie odpowiednich, efektywnych systemów i procedur ograniczających prawdopodobieństwo występowania zdarzeń niekorzystnych, sposobów ochrony przed ich skutkami, oraz ograniczeniem tych skutków [23, s. 25]. W związku z tym w Polsce wprowadzane są do krajowego porządku prawnego odpowiednie regulacje, których celem jest poprawa bezpieczeństwa narodowego. Ponadto jako strona konwencji międzynarodowych Polska jest związana postanowieniami tych dokumentów i od wielu lat sukcesywnie je wprowadza do krajowego systemu prawnego. W myśl art. 9 Konstytucji RP z 2 kwietnia 1997 r. „Rzeczpospolita Polska przestrzega wiążącego ją prawa międzynarodowego", zaś zgodnie z art. 87 ust. 1 ustawy zasadniczej „ratyfikowane umowy międzynarodowe są w Polsce źródłami powszechnie obowiązującego prawa".

W obszarze regulacji prawnych dotyczących przeciwdziałaniu terroryzmowi, poza normami prawa międzynarodowego, polskie prawodawstwo opiera się w zasadniczym stopniu na ustawach kompetencyjnych poszczególnych służb zaangażowanych w zwalczanie zagrożeń terrorystycznych oraz przepisów kodeksu karnego, a także przepisów ustawy o przeciwdziałaniu „praniu pieniędzy" oraz finansowaniu terroryzmu.

Zadania w zakresie szeroko pojętego zapewniania bezpieczeństwa wewnętrznego i porządku publicznego na terenie kraju są rozproszone w kilku resortach, instytucjach, organizacjach [24]:

1) administracja ogólna - Rada Ministrów, wojewoda, starosta oraz wójt;

2) cywilne służby specjalne - Agencja Bezpieczeństwa Wewnętrznego (ABW), Agencja Wywiadu (AW);

3) resort spraw wewnętrznych - Minister Spraw Wewnętrznych i Administracji (MSWiA), Policja, Straż Graniczna (SG), Państwowa Straż Pożarna (PSP), Biuro Ochrony Rządu (BOR), Prezes Urzędu ds. Repatriacji i Cudzoziemców, Szef Obrony Cywilnej Kraju;

4) resort obrony narodowej - Siły Zbrojne RP (SZ RP), Służba Wywiadu Wojskowego (SWW) i Służba Kontrwywiadu Wojskowego (SKW), Żandarmeria Wojskowa (ŻW), Jednostka Wojskowa 2305 (GROM);

5) organy finansowe - Generalny Inspektor Informacji Finansowej (GIIF), Służba Celna.

Złożoność w zakresie odpowiedzialności za realizację poszczególnych zadań w obszarze zarządzania kryzysowego spowodowanego terroryzmem widoczna jest również w Krajowym Planie Zarządzania Kryzysowego. Zgodnie z tym dokumentem, istnieją cztery fazy działania służb w tym obszarze: zapobieganie, przygotowanie, reagowanie oraz odbudowa. Za realizację każdego z tych zadań odpowiadają inne służby.

Do koordynacji działań związanych z przeciwdziałaniem terroryzmowi został powołany Międzyresortowy Zespół do spraw Zagrożeń Terrorystycznych jako organ pomocniczy Rady Mini- threats evolve both in terms of methods and responsibilities [21, p. 64]. In accordance with the National Security Strategy of the Republic of Poland, adopted by the President on 13 November 2007, Poland supports the development of international law and ensuring its universal observance, and aims at developing legal standards as effective tools in combatting the threats associated with the proliferation of weapons of mass destruction and terrorism [22, p. 14].

The essence of counteracting terrorism lies in implementing suitable and effective systems and procedures limiting the probability of adverse events, methods of protecting against their effects and limiting these effects [23, p. 25]. Therefore, suitable regulations are being introduced in Poland's legal order with the aim to enhancing national security. Furthermore, as a party to international conventions, Poland is bound by the provisions of these documents, and has been integrating these into the national legal system for many years. Pursuant to Article 9 of the Constitution of the Republic of Poland of 2 April 1997, "The Republic of Poland shall respect international law binding upon it.", and in accordance with Article 87 (1) thereof, "The sources of universally binding law of the Republic of Poland shall be: (...) ratified international agreements (...)."

In terms of legal regulations for counteracting terrorism, in addition to international law, Polish legislation is largely based on competence acts of the respective services involved in counteracting terrorist threats, and the provisions of the Criminal Code as well as the Act on counteracting money laundering and the financing of terrorism.

The tasks in the area of ensuring domestic security and public order in Poland are divided among several ministries, institutions and organisations [24]:

1) general administration - the Council of Ministers, the Voivodeship, District and Commune Governor;

2) civil special services - the Internal Security Agency (ABW), the Foreign Intelligence Agency (AW);

3) the Ministry of the Interior - the Minister of the Interior and Administration (MSWiA), the Police, the Border Guard (SG), the State Fire Service (PSP), the Government Protection Bureau (BOR), President of the Office for Foreigners, Head of the National Civil Defence of Poland;

4) the Ministry of National Defence - the Armed Forces of the Republic of Poland (SZ RP), the Military Intelligence Service (SWW) and the Military Counterintelligence Service (SKW), the Military Gendarmerie (ŻW), Military Unit 2305 (GROM);

5) financial authorities - the General Inspector of Financial Information (GIIF), the Customs Service.

The complexity of particular responsibilities in terms of terrorism-related crisis management is also reflected in the National Crisis Management Plan. Based on this document, there are four phases of the services' operations in this area: prevention, preparation, response and restoration. Each of these is the task of a different service.

To coordinate terrorism counteracting operations, the Inter-ministerial Team for Terrorist Threats acts as an auxiliary body of the Council of Ministers. In line with Ordinance No. 162 of the President of the Council of Ministers of 25 October 2006, as amended, the primary tasks of the team include: monitoring terrorist threats; presenting assessments and conclusions 
strów. Zgodnie z zarządzeniem nr 162 Prezesa Rady Ministrów z 25 października 2006 r. (wraz z późniejszymi zmianami) do podstawowych zadań Zespołu należy m.in.: monitorowanie zagrożeń o charakterze terrorystycznym, a także przedstawianie opinii i wniosków dla Rady Ministrów, opracowywanie propozycji zmierzających do usprawnienia metod i form zwalczania terroryzmu oraz występowanie z wnioskiem do właściwych organów o podjęcie w tym zakresie prac legislacyjnych, inicjowanie i koordynowanie działań podejmowanych przez właściwe organy administracji rządowej, organizowanie współpracy z innymi państwami w zakresie zwalczania terroryzmu [25].

W dniu 25 grudnia 2014 r. weszła w życie uchwała nr 252 Rady Ministrów z dnia 9 grudnia 2014 r. w sprawie ustanowienia "Narodowego Programu Antyterrorystycznego na lata 2015-2019". Program został opracowany w Ministerstwie Spraw Wewnętrznych we współpracy z innymi służbami, organami i instytucjami wchodzących w skład Międzyresortowego Zespołu ds. Zagrożeń Terrorystycznych. Założeniem Programu jest określenie niezbędnych działań państwa służących wzmocnieniu systemu antyterrorystycznego RP, a tym samym podniesieniu stanu przygotowania w przypadku wystąpienia ewentualnych zagrożeń o charakterze terrorystycznym [26].

Jedną z głównych ról w systemie antyterrorystycznym RP odgrywa Centrum Antyterrorystyczne (CAT) ABW, które w tym zakresie jest jednostką koordynacyjno-analityczną. CAT ABW koordynuje proces wymiany informacji między podmiotami systemu ochrony antyterrorystycznej [21, s. 65]. Szef ABW może udzielać zaleceń organom i podmiotom zagrożonym działaniami o charakterze terrorystycznym oraz przekazywać im niezbędne informacje służące przeciwdziałaniu takim zagrożeniom.

ABW jest instytucją właściwą do przeciwdziałania proliferacji BMR. Pod pojęciem proliferacja należy rozumieć zarówno rozprzestrzenianie BMR oraz środków jej przenoszenia, jak również materiały, surowce i urządzenia, które mogą mieć podwójne zastosowanie - w sektorze prywatnym i wojskowym. Polska uczestniczy swobodnie w handlu światowym i wymianie naukowo-technicznej, co jednak w pewien sposób implikuje zagrożenia związane z terroryzmem niekonwencjonalnym. W kompetencjach ABW jest opiniowanie wniosków o wydanie zezwolenia na międzynarodowy obrót towarami podwójnego zastosowania oraz zainicjowanie wszczęcia kontroli u przedsiębiorcy. Może także wystąpić o cofnięcie lub zmianę zakresu zezwolenia na obrót. Agencja jest jedyną w Polsce służbą specjalną o uprawnieniach śledczych, która ma ustawowy obowiązek rozpoznawania, przeciwdziałania i zwalczania przestępstw związanych z proliferacją. W realizacji tych zadań współpracuje przede wszystkim ze Służbą Celną i Strażą Graniczną oraz innymi służbami specjalnymi RP [27].

Ważną rolę w systemie bezpieczeństwa antyterrorystycznego pełni również Rządowe Centrum Bezpieczeństwa (RCB) realizujące zadania z zakresu przeciwdziałania, zapobiegania i likwidacji skutków zdarzeń o charakterze terrorystycznym we współpracy z organami rządowymi właściwymi w tych sprawach. Do podstawowych zadań RCB należy pełna analiza zagrożeń, dokonywana w oparciu o dane uzyskiwane od instytucji funkcjonujących w ramach administracji publicznej oraz partnerów międzynarodowych. Na ich podstawie RCB opracowuje optymalne rozwiązania pojawiających się sytuacji kryzysowych, a także koordynuje przepływ informacji o zagrożeniach. to the Council of Ministers; drawing up proposals aimed at streamlining the methods and forms of combatting terrorism, and submitting motions to the responsible bodies for launching legislative work; initiating and coordinating actions taken by the competent authorities of the governmental administration; organising cooperation with other countries in the area of combatting terrorism [25].

On 25 December 2014, Resolution No. 252 of the Council of Ministers of 9 December 2014 on establishing the National Anti-Terrorism Programme for the years 2015-2019 came into force". The programme was prepared by the Ministry of the Interior in cooperation with other services, authorities and institutions belonging to the Inter-ministerial Team for Terrorist Threats. The assumption of the Programme is to specify the essential measures of the state needed to strengthen the antiterrorism system of the Republic of Poland and to raise the preparedness level for countering potential terrorist threats [26].

One of the major roles in the antiterrorism system of the Republic of Poland is performed by the Counter-Terrorist Centre (CAT) of ABW, which is a coordination and analytical unit. CAT of ABW coordinates the information exchange process between units of the antiterrorism protection system [21, p. 65]. The Head of ABW can issue guidelines for bodies and entities under the threat of terrorist activities and provide them with the necessary information to counteract such threats.

ABW is an agency responsible for preventing the proliferation of WMDs. Proliferation should be understood as both the spreading of WMDs and their delivery vehicles and also materials, resources and equipment which can have a dual application - in the private and military sector. Poland freely participates in global trade and scientific and technological exchange, which, however, to some extent implies threats associated with unconventional terrorism. ABW's responsibilities include issuing assessment of applications for authorisations for international trade of dual-use items and initiating entrepreneur inspections. It also can apply for the withdrawal or change of scope of the authorisation. The Agency is the only special service in Poland with such investigative powers, and it is entrusted with a statutory duty to recognise, counteract and combat proliferation crimes. It cooperates primarily with the Customs Service and the Border Guard, as well as with other special services of the Republic of Poland [27].

An important role in the antiterrorism security system is also performed by the Government Security Centre (RCB), which carries out tasks involving counteracting, preventing and dealing with the consequences of terrorist events, in collaboration with the other responsible government bodies. The primary tasks of RCB include the comprehensive analysis of threats based on data obtained from institutions functioning within public administration, and from international partners. On their basis, RCB prepares optimum solutions of the encountered crisis situations and coordinates the flow of information on threats. Based on the relevant legal Act, RCB also develops the National Crisis Management Plan (KPZK). 
Zgodnie z ustawą RCB opracowuje Krajowy Plan Zarządzania Kryzysowego (KPZK).

W kwestii przeciwdziałania i zwalczania finansowania działalności terrorystycznej odpowiedzialne są przede wszystkim takie organy finansowe jak Generalny Inspektor Informacji Finansowej i Służba Celna.

W Polsce jest kilkanaście instytucji, które realizują zadania związane z zapobieganiem zagrożeniom terrorystycznym i nie ma jednego aktu prawnego, który kompleksowo regulowałby tę problematykę. Nieprecyzyjne określenie zadań i kompetencji poszczególnych podmiotów systemu bezpieczeństwa, odpowiadających za przeciwdziałanie terroryzmowi przy jednoczesnym braku właściwego poziomu koordynacji podejmowanych działań, stanowią istotne utrudnienie w zakresie współdziałania i współpracy w wymiarze krajowym i międzynarodowym [21, s. 64].

\section{Podsumowanie}

Polska nie stanowi priorytetowego celu dla organizacji terrorystycznych, niemniej jednak jako uczestnik koalicji antyterrorystycznej oraz członek UE i NATO znajduje się w kręgu zainteresowania jako potencjalny obszar ataku terrorystycznego.

Otwartość granic oraz jak podaje Międzynarodowe Centrum Antyterroryzmu (ICCT) to, że około cztery tysiące osób zamieszkujących nasz kontynent wstąpiło w szeregi tak zwanego Państwa Islamskiego wskazuje, że wielu europejczyków nie potrafi odnaleźć się w dotychczasowym otoczeniu, a to z kolei ma negatywny wpływ na poziom bezpieczeństwa w Europie.

Wielkim zagrożeniem, a zarazem wyzwaniem dla organizacji i instytucji międzynarodowych i krajowych odpowiedzialnych za bezpieczeństwo, jest fala migracji z rejonów zapalnych. Zaledwie w ciągu 2015 roku do Europy przybyło około miliona uchodźców. Przy tak masowym napływie ludności istnieje duże prawdopodobieństwa, że w ich szeregach znajdują się potencjalni terroryści. Należy jednak uwypuklić, że Polska jako jedno z nielicznych państw w Europie potrafi ograniczyć napływ ludności z zewnątrz, co minimalizuje ryzyko zagrożenia terrorystycznego.

Użycie BMR przez terrorystów mogłoby skutkować ogromnymi konsekwencjami, nie tylko ze względu na niewyobrażalną skalę ofiar i zniszczeń, lecz również z uwagi na bezprecedensowe efekty o charakterze politycznym, jak i społecznym oraz ekonomicznym. Szczególnie niebezpieczna jest broń biologiczna, która jest względnie mało kosztowna i łatwa w produkcji, ukryciu i przenoszeniu. Jednakże mimo dynamicznego rozwoju technicznego, zorganizowanie i przeprowadzenie zamachu terrorystycznego w szczególności tego z użyciem BMR, jest przedsięwzięciem bardzo skomplikowanym, lecz możliwym.

Zapobieganie zagrożeniom związanym z terroryzmem niekonwencjonalnym powinno być jednym z głównych zadań bezpieczeństwa narodowego. Działania w tym zakresie powinny być realizowane przez kontr-proliferację - ograniczenie rozprzestrzeniania BMR, kontrolę dostępu do technologii i materiałów - nieproliferację oraz efektywne opanowywanie i minimalizowanie skutków użycia tego rodzaju broni.

Należy podkreślić, że Polska posiada niezbędne siły i środki do przeciwdziałania terroryzmowi. Problem natomiast stanowi to, że odpowiedzialność w zakresie zapobiegania terroryzmu jest rozproszona w wielu resortach, instytucjach i organizacjach, co wpływa negatywnie na zapewnienie właściwego skutecznego
In terms of counteracting and combatting the financing of terrorist activities, the competent financial authorities are the General Inspector of Financial Information and the Customs Service.

There are over a dozen institutions in Poland which implement tasks associated with preventing terrorist threats, and there is no single legal act which regulates this issue in a comprehensive manner. The imprecise specification of tasks and responsibilities of particular security system entities responsible for counteracting terrorism, combined with the simultaneous lack of a sufficient coordination level of the measures undertaken, constitutes a significant obstacle to cooperation at both the national and international level [21, p. 64].

\section{Summary}

Poland does not constitute a priority target for terrorist organisations; however, as a member of the antiterrorist coalition, the EU and the NATO, it is within the scope of interest as a potential target of a terrorist attack.

Open borders, and, as stated by the International Centre for Counter-Terrorism (ICCT), the fact that approx. 4 thousand people living on our continent has joined the so-called 'Islamic State' indicate that many Europeans are unable to find their place in their society. This may have a negative impact on the security level in Europe.

A substantial threat and challenge for international and national organisations and institutions responsible for security, is the wave of migration from conflicted areas. In 2015 alone, approx. a million refugees came to Europe. With such a massive inflow of people, there is a strong possibility that potential terrorists will be among them. However, it should be emphasised that Poland as one of the few countries in Europe, is able to limit the inflow of foreign population, which minimises the threat of terrorism.

The use of MDWs by terrorists could have very serious consequences, not only due to the unimaginable scale of victims and destruction, but also due to the unprecedented effects that are of a political, social and economic nature. Biological weapons, which are relatively inexpensive, easy to produce, hide and transport, are particularly dangerous. However, despite the dynamic technological development, organising and carrying out a terrorist attack, especially with the use of MDWs, is a very complex, yet possible, undertaking.

Preventing threats related to unconventional terrorism should be one of the major responsibilities of national security. Measures in this respect should include: counter-proliferation - limitation of the acquisition of MDWs; nonproliferation - controlling access to technology and materials; and effective managing and minimising the effects of using such weapons.

It should be emphasised that Poland has the required forces and measures to counteract terrorism. The problem lies in the fact that responsibility for preventing terrorism is dispersed among many ministries, institutions and organisations, which negatively influences the capability of ensuring an effective level of coordination with regard to any undertaken measure. It is, therefore, recommended that we adopt 
poziomu koordynacji podejmowanych działań. Wskazane jest przyjęcie kompleksowych rozwiązań w zakresie zapobiegania zagrożeniom terrorystycznym, a przede wszystkim wprowadzenie regulacji prawnych dotyczących administrowania i zarządzania działaniami wszystkich służb odpowiedzialnych za przeciwdziałanie terroryzmowi. Ponadto $w$ dalszym ciągu należy współpracować z innymi państwami oraz organizacjami międzynarodowymi celem umacniania bezpieczeństwa narodowego.

\section{Literatura / Literature}

[1] Barnas R., Od Asasynów do Osamy bin Ladena, Wyd. Kirke, Wrocław 2001.

[2] Alexander Y., Swetnam M., Siewcy śmierci - Osama bin Laden i inni szefowie Al- Qaidy, Wyd. Bellona, Warszawa 2001.

[3] Madej M., Międzynarodowy terroryzm polityczny, Wyd. MSZ, Warszawa 2001.

[4] European Union Terrorism Situation And Trend Report 2016.

[5] Al Jazeera and agencies, Islamic State has 50,000 fighters in Syria, http:// www.aljazeera.com/news /middleeast/2014/08/islamic-state-50000fighters-syria-2014819184258421392.html [dostęp: 15.03.2016].

[6] Obrona Cywilna - Dział Spraw Obronnych i Ochrony, Aktualny stan zagrożeń terrorystycznych, http://www.us.edu.pl/uniwersytet/obrona/ter5.php [dostęp: 29.03.2016].

[7] Narodowy Program Antyterrorystyczny na lata 2015-2019, załącznik do uchwały nr 252 Rady Ministrów z dnia 9 grudnia 2014 r. (MP poz. 1218), Warszawa 2014.

[8] Obrona przed bronią masowego rażenia w operacjach połączonych (DD/3.8), MON, Warszawa 2004

[9] Weapons of Mass Destruction, http://www.globalsecurity.org/ wmd/systems/w54.htm, [dostęp: 26.05.2017].

[10] Adamski J., Ewolucja form działalności terrorystycznej na tle postępu technologicznego, rozprawa doktorska, Wyd. AON, Warszawa 2004.

[11] Departments of the Army, the Navy and the Air Force, NATO Handbook on the medical aspects of NBC defensive operation, part 2 Biological, NATO AMedP-6 (B) Anonymous, 1996.

[12] Agencja standaryzacyjna NATO, AAP-6 Słownik terminów i definicji NATO zawierający wojskowe terminy i ich definicje stosowane w NATO, 2014.

[13] Michailiuk B., Broń biologiczna i bioterroryzm, „Zeszyty Naukowe AON" 2016, 1(102).

[14] Osiński R., Bioterroryzm, Wąglik - postępowanie, Bydgoszcz 2003.

[15] Żuber M., Katastrofy naturalne i cywilizacyjne zagrożenia cywilizacyjne początku XXI wieku, Obrona przed bronią masowego rażenia w aspekcie zagrożenia superterroryzmem, Wyd. WSOWL, Wrocław 2007.

[16] Machnikowski R., Michalak J., Płaczek A., Rękawek K., Dziuba M., Zagrożenie atakami terrorystycznymi w Polsce, raport, Wyd. Wyższa Szkoła Studiów Międzynarodowych, Łódź 2006.

MJR MGR INŻ. PAWEŁ LECH - zastępca dowódcy, szef sztabu 1 batalionu logistycznego. Absolwent Wyższej Szkoły Oficerskiej we Wrocławiu, Akademii Obrony Narodowej w Warszawie oraz podyplomowych studiów na kierunku ochrona ludności i zarządzania kryzysowego Uniwersytetu Kazimierza Wielkiego w Bydgoszczy. Obecnie student studiów doktoranckich na Wydziale Bezpieczeństwa Narodowego Akademii Sztuki Wojennej w Warszawie. comprehensive solutions for preventing terrorist threats, in particular, to introduce legal regulations on administering and managing the activities of all services responsible for counteracting terrorism. Furthermore, cooperation with other countries and international organisation should be continued to further strengthen our national security.

[17] Williams P.L., Al-Kaida. Bractwo terroru, Studio EMKA, Warszawa 2002.

[18] Towpik A., Terroryzm a broń masowego rażenia. Diagnoza, poglądy, wnioski, „Zeszyty Naukowe AON"2003, 1(50)A.

[19] The National Center for Biotechnology Information, Terrorism in Japan, https://www.ncbi.nlm.nih.gov/pubmed/15074491[dostęp: 29.05.2016].

[20] Żuber M., Katastrofy naturalne i cywilizacyjne. Terroryzm współczesny. Aspekty polityczne, społeczne i ekonomiczne, Wyd. WSOWL, Wrocław 2006.

[21] Biała Księga Bezpieczeństwa Narodowego Rzeczypospolitej Polskiej, Wyd. BBN, Warszawa 2013.

[22] Strategia Bezpieczeństwa Narodowego RP, Warszawa 2007.

[23] Sulowski S., Brzeziński M., Bezpieczeństwo wewnętrzne państwa. Wybrane zagadnienia, Wyd. Dom Wydawniczy ELIPSA, Warszawa 2009.

[24] Centrum Badań nad Terroryzmem, Zmiany w systemie przeciwdziałania terroryzmowi w Polsce, http://www.cbnt.collegium.edu. $\mathrm{pl} /$ index.php?option=com_content\&view $=$ article\&id=49:zmiany- $w$-systemie-przeciwdziaania-terroryzmowi-w-polsce \&catid=34: analizy-i-raporty [dostęp: 29.03.2016].

[25] Zarządzenie nr 162 Prezesa Rady Ministrów z dnia 25 października 2006 r. w sprawie utworzenia Międzyresortowego Zespołu do Spraw Zagrożeń Terrorystycznych wraz z późniejszymi zmianami: zarządzeniem nr 95 Prezesa Rady Ministrów z dnia 4 września 2008 r., zarządzeniem nr 74 Prezesa Rady Ministrów z dnia 21 września 2009 r., zarządzeniem nr 18 Prezesa Rady Ministrów z dnia 3 kwietnia 2014 r., zarządzeniem nr 84 Prezesa Rady Ministrów z dnia 18 września 2015 r. oraz zarządzeniem nr 86 Prezesa Rady Ministrów z dnia 5 lipca 2016 r.

[26] Narodowy Program Antyterrorystyczny na lata 2015-2019, załącznik do uchwały nr 252 Rady Ministrów z dnia 9 grudnia 2014 r. (MP poz. 1218), Warszawa 2014.

[27] Agencja Bezpieczeństwa Wewnętrznego, Przeciwdziałanie proliferacji BMR, https://www.abw.gov.pl/pl/zadania/przeciwdzialanie-proli/8,Przeciwdzialanie-proliferacji -BMR.html [dostęp: 25.03.2016].

[28] Michailiuk B., Terroryzm bronią masowego rażenia jako zagrożenie bezpieczeństwa, [w.] Katastrofy naturalne i cywilizacyjne. Zagrożenia i wyzwania dla bezpieczeństwa, Żuber M. (red.), tom 2, WSOWL, Wrocław 2009.

PAWE LECH, MAJOR M.Eng. - Deputy Commander, Chief of Staff of the 1st Logistics Battalion. Graduate of the Military Academy of Armed Forces in Wrocław, the National Defence University in Warsaw and of the Kazimierz Wielki University in Bydgoszcz (post-graduate studies in the field of "Civil protection and crisis management"). Currently a PhD student at the Faculty of National Security of the War Studies University in Warsaw.

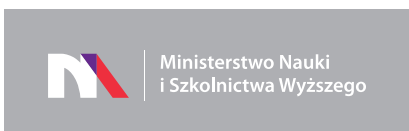

Artykuł został przetłumaczony ze środków MNiSW w ramach zadania: Stworzenie anglojęzycznych wersji oryginalnych artykułów naukowych wydawanych w kwartalniku „BiTP. Bezpieczeństwo i Technika Pożarnicza” - typ zadania: stworzenie anglojęzycznych wersji wydawanych publikacji finansowane w ramach umowy 935/P-DUN/2016 ze środków Ministra Nauki i Szkolnictwa Wyższego przeznaczonych na działalność upowszechniającą naukę. 